\title{
Leið̌in til lýðheilsu: forvarnir og heilsuefling
}

Markmið íslenskra stjórnmálamanna á næstu misserum ætti að vera að finna leiðir til góðs öldrunarsamfélags. Petta markmið ætti einnig að fá aukið vægi í námi og starfi lækna og heilbrigðisstarfsfólks par sem heilsuefling, forvarnir á sviði heilsu og velferðar, greiða götu okkar að bættri lýðheilsu.

Langvinnir sjúkdómar eru og verða helsta ógn við heilbrigði, framfarir og hagvöxt um allan heim á næstu árum og áratugum. Flestir langvinnir sjúkdómar eru til komnir vegna slæmra lifnaðarhátta sem pjóðir hafa tamið sér síðustu 50 ár. ${ }^{1}$ Með einföldum og ódýrum stjórnvaldsaðgerðum má ná miklum árangri á skömmum tíma. Рað má takmarka nokkra vel pekkta áhættupætti með einföldum aðgerðum sem hafa haft veruleg áhrif á heilsu og velferð okkar á síðustu áratugum. ${ }^{2,3}$ Að viðhalda heilbrigði í stað pess að meðhöndla einungis sjúkdóma er mun ódýrari og áhrifaríkari nálgun að bættri lýðheilsu. Læknar og heilbrigðisstarfsfólk hafa mikilvægu hlutverki að gegna til að upplýsa heilbrigðisyfirvöld um orsakir sjúkdóma. Íprótta- og heilsufræðingar geta lagt pessu fagfólki lið og beitt áhrifaríkum inngripum til að fyrirbyggja langvinna sjúkdóma í okkar samfélagi. Hér leynast tækifæri til frampróunar heilbrigðisstétta.

Heilbrigðisstarfsfólk, með lækna í broddi fylkingar, parf að leggja meiri áherslu á að viðhalda heilbrigði frá unga aldri til viðbótar pví að meðhöndla sjúkdóma. Til lengri tíma litið eru fyrirbyggjandi aðgerðir á heilsu mun ódýrari og áhrifaríkari nálgun til bættrar lýðheilsu án pess að hverfa frá markvissri og góðri heilbrigðispjónustu. Um 98\% útgjalda til heilbrigðismála fer í að meðhöndla sjúkdóma en aðeins tæplega 2\% til að fyrirbyggja vandann. Hvaða rök liggja að baki pessari stefnu?

Раð er áhugaverð staðreynd að í Evrópu fara tæplega 3\% útgjalda til heilbrigðismála í forvarnir málaflokksins en á Íslandi er hlutfallið nær helmingi lægra, eða um 1,6\%. ${ }^{4}$ Pað skýtur pví skökku við að heilbrigðiskerfið er fyrst og fremst byggt upp til að meðhöndla sjúkdóma eða bregðast við bráðatilfellum; leggja plástur á sárin, í stað pess að fyrirbyggja pessa pætti.

Læknarnir Karl Andersen og Vilmundur Guðnason fjalla í tveimur greinum sínum í Læknablaðinu um langvinna sjúkdóma og leiðir til bættrar lýðheilsu. ${ }^{1,5}$ Peir benda á lausnir og fjalla um faraldur langvinnra sjúkdóma sem orsakir að flestum dauðsföllum í heiminum. Peir benda á að sjúkdómar pessir hindra einnig framfarir, hagvöxt og heilbrigði og að slík próun mun halda áfram á næstu tveimur til premur áratugum verði ekkert að gert. Aðrir sérfræðingar taka undir pessa nálgun. ${ }^{6,7}$ Forvörn á sviði heilsu og velferðar er eins og fársjúkur einstaklingur á bráðamóttöku, polir enga bið.

Langlífi hefur aukist og sífellt stærra hlutfall pjóðar nær eftirlaunaaldri. En langlífi er einnig afleiðing af breyttum lífsstíl pjóðar og menningu. Með enn betri sampættingu læknisfræðinnar og lýðheilsufræðilegra inngripa má gera betur innan öldrunarsamfélags framtíðar. Рað hlýtur að vera eftirsóknarvert að takast á við pær breytingar og fækka langvinnum sjúkdómum í stað pess að sjá pá aukast á næstu árum og áratugum.
Talið er að um 40\% fullorðinna í Evrópu eigi að minnsta kosti við einn langvinnan sjúkdóm að stríða og tveir priðju hlutar peirra sem ná eftirlaunaaldri hafi tvo eða fleiri langvinna sjúkdóma. Petta er sagt par sem pað er bæði kostnaðarsamt að vera undir stöðugu eftirliti starfsmanna heilbrigðiskerfisins og lyf eru dýr.

Ekki er hægt að ljúka pessari umfjöllun án pess að nefna helstu áhættupætti langvinnra sjúkdóma og hvar rætur peirra liggja. Hjartaog æðasjúkdómar eru algengasta orsök langvinnra sjúkdóma. Um 90\% af öllum nýjum tilfellum kransæðastíflu orsakast af 9 algengum áhættupáttum sem eiga рað sameiginlegt að vera tengdir við lífsstíl og umhverfi. ${ }^{8}$

Hjartavernd, sú einstaka stofnun í Kópavogi og sérfræðingar hennar, hefur komist að pví að síðastliðin 25 ár hefur orðið 66\% fækkun tilfella af bráðri kransæðastíflu. Pessi breyting hefur skilað sér í 80\% fækkun dauðsfalla að mati Thors Aspelund og sérfræðinga par á bæ. ${ }^{9}$ Skýringa á pessum jákvæðu breytingum var að fjórðungi að leita 1 læknisfræðinni og meðferðum lækna og heilbrigðisstarfsfólks við pessum sjúkdómum. En að premur fjórðu hlutum var breytingin skýrð af jákvæðum breytingum í helstu áhættupáttum meðal pjóðarinnar; reykingum, háu kólesteróli og háum blóðprýstingi. Flestir pessara pátta eiga rætur að rekja til lífsstílsbreytinga einstaklinga sem létu af óhollu mataræði og hreyfingarleysi. Pví miður vann sykursýki og offita á móti enn betri árangri.

Ef við ætlum okkur að sinna heilbrigðismálum eins og heilsa er skilgreind, bæta heilsutengd lífsgæði allra aldurshópa og verða fær um að sinna ört stækkandi öldrunarsamfélagi framtíðar, er pað lykilatriði að auka heilsutengdar forvarnir par sem bætt og breytt mataræði, dagleg hreyfing og félagsleg aðhlynning einstaklinga og hópa er höfð að leiðarljósi.

Aukið framlag ríkisins til forvarna heilsueflingar um aðeins 2-3\% af heildarframlagi til heilbrigðismála gæti skipt sköpum fyrir íslenska pjóð til frambúðar svo vinda megi ofan af langvinnum sjúkdómum, sinna ört vaxandi eldra samfélagi og auka jafnvægi í útgjöldum til heilbrigðismála á næstu árum og áratugum.

\section{Heimildir}

1. Andersen K, Gudnason V. Langvinnir sjúkdómar. Læknablaðið 2012; 98: 591-5.

2. Gữlaugssson J, Aspelund T, Gữnason V, Ólafsdóttir AS, Jónsson PV, Arngrímsson SÁ, et al. Áhrif 6 mánað̌ fjölbættrar pjálfunar á hreyfigetu, vöðvakraft, pol og líkamspyngdar eldri einstaklinga - Eru áhrif pjálfunar mbærileg hjá konum og körlum? Læknablað̌ið 2013; 99: 331-7.

Guőlaugsson J, Gữnason V, Aspelund T, et al. Effects of exercise training and nutrition counseling on body composition and cardiometabolic factors in old individuals. Eur Geriat Med 2013; 4: 431-7.

4. Chabot JM. [Health at a glance by OECD]. Rev Prat 2003; 53: 1929-30.

6. Petersen $\mathrm{PE}$. Global policy for improvement of oral heath in the 21st century-implications to oral health researc of World Health Assembly 2007, World Health Organization. Community Dent Oral Epidemiol 2009; 37: 1-8. . Olshansky SJ, Passaro DJ, Hershow RC, Layden J, Carnes BA, Brody J, et al. A potential decline in life expectancy in the United States in the 21st century. N Engl J Med 2005; 352: 1138-45.

Yusuf S, Hawken S, Ounpuu S, Dans T, Avezum A, Lanas F, et al. Effect of potentially modifiable risk factor associated with myocardial infarction in 52 countries (the INTERHEART study): case-control study. Lancet 2004; 364: 937-52

Aspelund T, Gudnason V, Magnusdottir BT, Andersen K, Sigurdsson G, Thorsson B, et al. Analysing the large decline in coronary heart disease mortality in the Icelandic population aged 25-74 between the years 1981 and 2006. PloS one 2010; 5: e13957. 